ACTA AGROBOTANICA

Vol. 57, z. 1-2 - 2004

s. $255-267$

\title{
Występowanie Equisetum telmateia Ehrh. w użytkach rolnych
}

\section{DOMINIK WRÓBEL}

Instytut Botaniki PAN im. Wł. Szafera w Krakowie, PAN

W. Szafer Institute of Botany, Polish Academy of Sciences

ul. Lubicz 46, 31-512 Kraków

(Otrzymano: 22.10.2003)

Summary

Equisetum telmateia Ehrh. rather often occurs in agricultural lands communities. According to the literature and one's own original research, one constructs his list which contains 16 communities, associations and subassociations (Vicietum tetraspermae, Aphano-Matricarietum, Lathyro-Melandrietum noctiflori, Echinochloo-Setarietum, Galinsogo-Setarietum, Cirsietum rivularis, Cirsietum rivularis caricetosum hartmanii, Scirpetum sylvatici, community with Mentha longifolia, community with Equisetum telmateia, Arrhenatheretum medioeuropaeum, Arrhenatheretum medioeuropaeum brizetosum mediae, community with Cirsium oleraceum, Lolio-Cynosuretum, Valeriano-Caricetum flavae, Carlino Dianthetum deltoidis). The occurrence of Giant horsetail in such differentiated communities points to its wide ecological scale and the ability to survive in different forms of anthropogenic pressure. The appearance of this species in agricultural land communities may be result of its previous existence on the land that started to be cultivated land or of the vegetative spreading of its rhizomes.

Key words: phytosociology, Equisetum telmateia, agricultural lands communities

\section{WSTĘP}

Skrzyp olbrzymi (Equisetum telmateia Ehrh.), tradycyjnie zaliczany do gatunków łęgowych, ostatnio coraz częściej pojawia się na siedliskach antropogenicznych. Jak wynika z obserwacji autora, wykonanych w latach 2000-2003, najczęściej ma to 
miejsce w płatach zbiorowisk i zespołów zaliczanych do klasy Artemisietea vulgaris (B rze g, 1988; Wróbe 1, 2003). Nierzadko również, gatunek ten pojawia się w płatach zespołów pastwiskowych, łąkowych i segetalnych, stając się niekiedy uciążliwym chwastem. Skąpa literatura, dotycząca tego tematu mogłaby sugerować, że jest to zjawisko rzadkie. Jednak analiza występowania skrzypu olbrzymiego w Karpatach, ujawnia, że jest to zjawisko dość częste na pogórzu Karpat i zwykle związane z nieodległym, spontanicznym wystąpieniem (Wróbe 1, 2003).

Celem tej pracy jest sporządzenie w miarę pełnej listy zbiorowisk i zespołów fitosocjologicznych w użytkach rolnych, w których stwierdzono występowanie skrzypu olbrzymiego. Stanowi to część szerzej zakrojonych badań nad spektrum fitocenotycznym tego gatunku.

Badania były częściowo finansowane ze środków grantów KBN P04G\034121 oraz P04G\005\24.

\section{MATERIAŁ I METODY}

Przy konstruowaniu zestawienia zespołów i zbiorowisk oraz ich opisów wykorzystano głównie dane publikowane. Wśród nich dwie prace dotyczą Pogórza Wielickiego (Dubiel, Trzcińska-Tacik, 1982; Dubiel, 1984), jedna Wysoczyzny Staniszewskiej na Pojezierzu Kaszubskim (Herbich, 1982), jedna terenu Magurskiego Parku Narodowego (Dubiel, Stachurska, Gawroński, 1999) i ostatnia Dolnego Śląska (Wróbe l, 2003). Do publikacji wybrano również 8 najbardziej interesujących zdjęć fitosocjologicznych autora, wykonanych w oparciu o klasyczną metodę Braun-Blanqueta. Dokumentują one zbiorowiska, których płaty ze skrzypem olbrzymim dotąd rzadko lub w ogóle nie były opisywane. Zespoły (zbiorowiska), dla których dołączono dokumentację fitosocjologiczną oznaczono znakiem ,!!'. Przy pozostałych zespołach i zbiorowiskach podano źródło, w którym znajduje się tabela fitosocjologiczna. Za użytek rolny uznano pola zajęte przez uprawy zbożowe, roślin okopowych oraz łąki i pastwiska oraz te zbiorowiska, które z fitosocjologicznego punktu widzenia nie są ani łąkami ani pastwiskami, lecz są lub mogą być wykorzystywane kośnie i pastwiskowo. 
Tabela 1. Equisetum telmateia w zbiorowiskach użytków rolnych

Tabel 1. Equisetum telmateia in agricultural land communities

\begin{tabular}{|c|c|c|c|c|c|c|c|c|c|c|c|c|c|c|c|c|c|}
\hline Lp. & 1 & 2 & 3 & 4 & 5 & 6 & 7 & 8 & 9 & 10 & 11 & 12 & 13 & 14 & 15 & 16 & 17 \\
\hline $\begin{array}{l}\text { Zespół / } \\
\text { Zbiorowisko } \\
\text { (Association / } \\
\text { Community) }\end{array}$ & 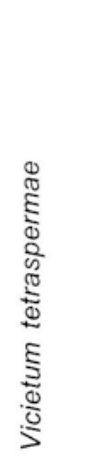 & 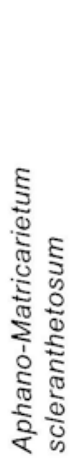 & 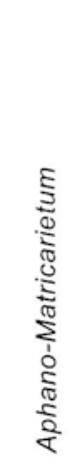 & 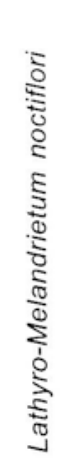 & 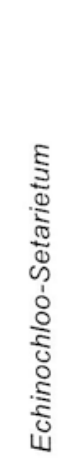 & 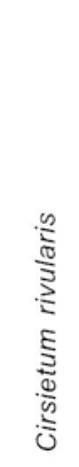 & 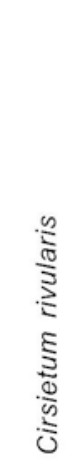 & 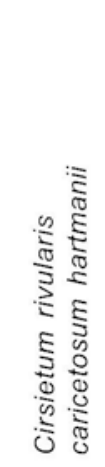 & 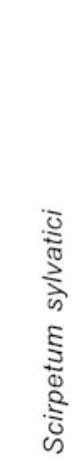 & 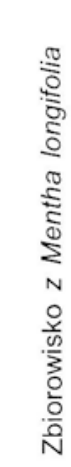 & 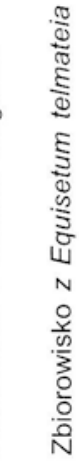 & 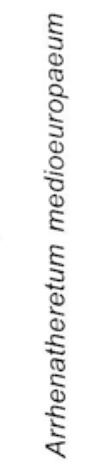 & 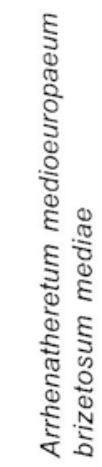 & 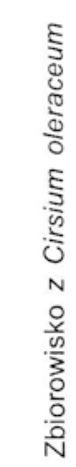 & 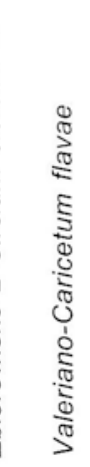 & 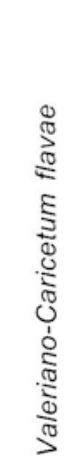 & 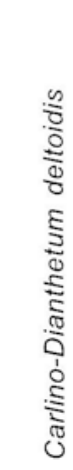 \\
\hline $\begin{array}{l}\text { Autorzy } \\
\text { (Authors) }\end{array}$ & 2 & 4 & 5 & 2 & 2 & 1 & 3 & 3 & 1 & 1 & 1 & 1 & 3 & 1 & 1 & 3 & 3 \\
\hline $\begin{array}{l}\text { Klasa stałości } \\
\text { (Constancy) }\end{array}$ & 1 & 1 & - & I & 1 & II & 1 & 1 & 1 & 1 & V & 1 & II & II & II & 1 & \\
\hline $\begin{array}{l}\text { Współczynnik } \\
\text { pokrycia } \\
\text { (Cover coefficient) }\end{array}$ & + & 1 & +-1 & + & + & + & 2 & + & 2 & 1 & $4-5$ & + & + & +-3 & $1-3$ & 1 & + \\
\hline $\begin{array}{l}\text { Liczba zdjęć } \\
\text { (Number of relievés) }\end{array}$ & $1 / 23$ & $1 / 10$ & $2 / 2$ & $1 / 7$ & $3 / 12$ & $2 / 20$ & $1 / 20$ & $1 / 10$ & $1 / 7$ & $1 / 5$ & $6 / 6$ & $1 / 20$ & $1 / 5$ & $4 / 9$ & $2 / 8$ & $3 / 10$ & $1 / 15$ \\
\hline
\end{tabular}

1. - Dubiel E. 1984. Dolina Wierzbanówki 10: Zbiorowiska łąkowe. Zesz. Nauk. Uniw. Jagiellońskiego, Prace bot. 14:51-86.

2. - Dubiel E., Trzcińska-Tacik H. 1982. Dolina Wierzbanówki 4: Zbiorowiska roślinne pól uprawnych. Zesz. Nauk. Uniw. Jagiellońskiego, Prace bot. $12: 51-86$. 3. - Dubiel, Stachurska, Gawroński 1999. Nieleśne zbiorowiska roślinne Magurskiego Parku Narodowego (Beskid Niski). Zesz. Nauk. Uniw. Jagiellońskiego, Prace bot. 33:1-60.

4. - Herbich J., 1982. Zróżnicowanie i antropogeniczne przemiany roślinności Wysoczyzny Staniszewskiej na Pojezierzu Kaszubskim. Monogr. Bot. 62:1-162. 5. - Wróbel D. 2003. Występowanie Equisetum telmateia Ehrh. w antropogenicznych zbiorowiskach roślinnych na terenie Karpat i Dolnego Śląska. Fragm. Flor. Geobot. Polonica 10: 27-55.

Liczba zdjęć (Number of relievés): liczba zdjęć z E. telmateia / liczba zdjęć w tabeli (number of relievés with E. telmateia / number of relievés in the table) 


\section{WYNIKI}

Lista zbiorowisk

W oparciu o literaturę i własne badania terenowe stwierdzono występowanie Equisetum telmateia w zbiorowiskach roślinnych, których systematyka (wg Matuszkiewicza, 2001) jest następująca:

1. Stellarietea mediae R. Tx., Lohm. et Prsg 1950

1.1. Centauretalia cyani $\mathrm{R}$. Tx. 1950

1.1.1. Aphanenion arvensis R. Tx. et J. Tx. 1960

1.1.1.1. Vicietum tetrasperamae (Krusem. et Vlieg. 1939) Kornaś 1950; (Dubiel, Trzcińska-Tacik, 1982)

1.1.1.2. Aphano-Matricarietum R. Tx. 1937; (Herbich, 1982; Wróbel, 2003) 1.1.2. Caucalidion lappulae R. Tx. 1950

1.1.2.1. Lathyro-Melandrietum noctiflori Oberd. 1957; (Dubiel, TrzcińskaTacik, 1982)

2.1. Polygono-Chenopodietalia (R. Tx. et Lohm. 1950) J. Tx. 1961

2.1.1. Panico-Setarion Siss. 1946

2.1.1.1. (!) Echinochloo-Setarietum Krusem. et Vlieg. (1939) 1940; (Dubiel, 1984)

2.1.2. Polygono-Chenopodion Siss. 1946

2.1.2.1.(!) Galinsogo-Setarietum (R. Tx. et Beck. 1942) R. Tx. 1950

3. Molinio-Arrhenatheretea R. Tx. 1937

3.1. Molinietalia coeruleae W. Koch 1926

3.1.1. Calthion palustris R. Tx. 1936 em. Oberd. 1957

3.1.1.1.A. Cirsietum rivularis Nowiński 1927; (D u bi e 1, 1984; D u b i e 1, S ta ch u rska, Gawroński, 1999)

3.1.1.1.B. Cirsietum rivularis caricetosum hartmanii; (Dubiel, Stachurska, Gawroński, 1999)

3.1.1.2. Scirpetum sylvatici Ralski 1931; (Dubie 1, 1984)

3.1.1.3. Zbiorowisko z Mentha longifolia; (D u bie 1, 1984)

3.1.1.4. Zbiorowisko z Equisetum telmateia; (D u bi e 1, 1984)

3.2. Arrhenatheretalia Pawł. 1928

3.2.1. Arrhenatherion elatioris (Br.-B1. 1925) Koch 1926

3.2.1.1.A. Arrhenatheretum medioeuropaeum Br.-Bl. ex Scherr. 1925; (D u b i e 1, S ta churska, Gawroński, 1999)

3.2.1.1.B. Arrhenatheretum medioeuropaeum brizetosum mediae; (Dubiel, 1984)

3.2.2.1. Zbiorowisko z Cirsium oleraceum; (D u bi e l, 1984)

3.2.2. Cynosurion R. Tx. 1947

3.2.2.1. (!) Lolio-Cynosuretum R. Tx. 1937 
4. Schechzerio-Caricetea (Nordh. 1937) R. Tx. 1937

4.1. Caricetalia davallianae Br. Bl. 1949

4.1.1. Caricion davallianae Klika 1934

4.1 1.1. Valeriano-Caricetum flavae Pawł. (1949 n.n.) 1960; (Dubiel, 1984, Dubiel, Stachurska, Gawroński, 1999)

5. Nardo-Callunetea Prsg. 1949

5.1. Nardetalia Prsg. 1949

5.1 1. Violion caninae Schwick. 1934

5.1.1.1. Carlino-Dianthetum deltoidis; (Dubie l, Stachurska, Gawroński, 1999)

Charakterystyka zbiorowisk

\section{Vicietum tetraspermae}

Zespół ten jest najbardziej rozpowszechniony spośród zbiorowisk związku Aphanion. Płaty, w których obecny był Equisetum telmateia opisywane były z doliny Wierzbanówki (Dubiel, Trzcińska-Tacik, 1982). Gatunek ten występuje tam w podzespole typowym, postaci Melampyrum arvense.

\section{Aphano-Matricarietum}

Zbiorowisko to ma charakter suboceaniczny. Płat z udziałem Equisetum telmateia opisywał Herbich (1982). Zanotował on jedno wystąpienie tego gatunku w uprawie jarej, w podzespole scleranthetosum, wariancie typowym. Płaty takie wykształcały się na ługowanych kwaśnych glebach o znacznej wilgotności, o czym świadczy występowanie gatunków higrofilnych. Zespół ten na Wysoczyźnie Staniszewskiej posiada swoje krańcowe wystąpienia.

Zubożałe płaty Aphano-Matricarietum stwierdzono w Muszkowicach na Dolnym Śląsku, w pobliżu rezerwatu ,Muszkowicki Las Bukowy”, w uprawie Triticum aestivum znajdującej się na niezbyt rozległej, słabo nachylonej w kierunku wschodnim, płaszczyźnie, wyraźnie zaznaczającej się wśród otaczających ją form terenowych. Poziom wód gruntowych położony jest na głębokości $30-50 \mathrm{~cm}$. W płatach tych nie występował w ogóle Aphanes arvensis, natomiast duży udział wykazywały Myosotis arvensis i Urtica dioica oraz Equisetum telmateia.

\section{Lathyro-Melandrietum}

W tabeli tego zespołu $\mathrm{z}$ doliny Wierzbanówki znajduje się jedno zdjęcie fitosocjologiczne z udziałem Equisetum telmateia. Płaty takie wykształciły się na glebach o charakterze zbliżonym do rędzin, o pH obojętnym. 


\section{Echinochloo-Setarietum}

Zbiorowisko podawane z doliny Wierzbanówki (Dubie l, Trzc i ńs ka - Ta c i k 1984). Jego płaty występują na zboczach i wierzchowinach, na glebach płowych, gliniastych o kwaśnym odczynie, zasobnych w azot. Płat z Equisetum telmateia jest stosunkowo suchy i jednocześnie posiada najniższe $\mathrm{pH}$, spośród reprezentowanych w zamieszczonej tam tabeli.

W 2003 roku w Warzycach koło Jasła znaleziono płaty tego zbiorowiska z Equisetum telmateia w uprawach Solanum tuberosum oraz Beta vulgaris var. crassa (Tabela 2). Stanowisko to znajduje się na terasie zalewowej Jasiołki, jednak w dość dużej odległości od jej koryta. Od drogi Jasło - Krosno oddziela je pas ugoru. Obejmuje kilka poletek, na których uprawia się ziemniaki oraz buraki i kapustę. Uprawa ziemniaków jest zdominowana przez Equisetum telmateia.

Tabela 2. (Table 2.) Echinochloo-Setarietum Krusem. et Vlieg. (1939) 1940

\begin{tabular}{|c|c|c|}
\hline Nr kolejny zdjęcia (Successive no. of relevé) & 1 & 2 \\
\hline Data (Date) & 28.08.2003. & 28.08.2003. \\
\hline Stanowisko (Locality) & Warzyce & Warzyce \\
\hline Powierzchnia (Area) $\mathrm{m}^{2}$ & 100 & 25 \\
\hline Pokrycie roślin uprawnych (Cover of cultivation) [\%] & 15 & 75 \\
\hline Pokrycie warstwy c (Cover of layer c) [\%] & 80 & 5 \\
\hline \multicolumn{3}{|l|}{ Uprawa (Cultivation): } \\
\hline Solanum tuberosum & 2 & . \\
\hline Beta vulgaris var. crassa & . & 4 \\
\hline \multicolumn{3}{|l|}{ Ch. Echinochloo-Setarietum et Ch. Panico-Setarion ${ }^{\star}$} \\
\hline Echinochloa crus-galli & 1 & + \\
\hline *Setaria viridis & + & + \\
\hline \multicolumn{3}{|l|}{ Ch. Polygono-Chenopodietalia } \\
\hline Chenopodium album & + & 1 \\
\hline Chenopodium polyspermum & + & $\mathrm{r}$ \\
\hline Galinsoga ciliata & $r$ & . \\
\hline Geranium pusillum & $r$ & . \\
\hline Sonchus oleraceus & . & + \\
\hline \multicolumn{3}{|l|}{ Ch. Stellarietea mediae } \\
\hline Stellaria media & + & + \\
\hline Myosotis arvensis & + & + \\
\hline Thlaspi arvense & $r$ & . \\
\hline \multicolumn{3}{|l|}{ Inne (Others) } \\
\hline Equisetum telmateia & 4 & + \\
\hline Symphytum officinale & + & + \\
\hline Equisetum arvense & + & $r$ \\
\hline Capsella bursa-pastoris & $r$ & $r$ \\
\hline \multicolumn{3}{|c|}{$\begin{array}{l}\text { Sporadyczne (Sporadic): Convolvulus arvensis } 1(1) \text {, Polygonum persicaria } 1(+) \text {, } \\
\text { Stachys palustris } 1(\mathrm{r}), \text { Plantago major } 2(+)\end{array}$} \\
\hline
\end{tabular}


Galinsogo-Setarietum (Tabela 3).

Jest to pospolite zbiorowisko upraw okopowych o charakterze przyzagrodowym. Zdjęcia fitosocjologiczne nr 1 i 2 płatów tego zbiorowiska wykonano w Brzezówce na Pogórzu Jasielskim w uprawie Solanum tuberosum. Jest ono wilgotne i sąsiaduje z zaroślami łęgowymi. Dodatkowym czynnikiem zwiększającym wilgotność podłoża jest woda gromadząca się po intensywnych opadach u podnóża pobliskiego nasypu kolejowego. Pomiary kwasowości, dokonane przy użyciu płynu Helliga, wskazywały na pH 5-6. Poletko to ma powierzchnię około pół hektara i jest w całości obrabiane ręcznie, bez użycia maszyn. Nie stosowano też chemicznego odchwaszczania. W obu płatach dominantami wśród chwastów są Galinsoga ciliata i Echinochloa crus-galli. Pozostałe gatunki nie osiągały wysokich ilościowości z wyjątkiem Equisetum telmateia i w pierwszym zdjęciu Symphytum officinale. Podobne płaty obserwowano także w innych miejscach, m.in. w Jaszczwi oraz w Topolinach w Kotlinie Jasielsko-Krośnieńskiej.

Tabela 3. (Table 3.) Galinsogo-Setarietum (R. Tx. et Beck. 1942) R. Tx. 1950

\begin{tabular}{|c|c|c|c|}
\hline Nr kolejny zdjęcia (Successive no. of relevé) & 1 & 2 & 3 \\
\hline Data (Date) & 31.07.2000. & 31.07 .2000 . & 28.08.2003. \\
\hline Stanowisko (Locality) & Brzezówka & Brzezówka & Warzyce \\
\hline Powierzchnia (Area) $\mathrm{m}^{2}$ & 100 & 100 & 15 \\
\hline Pokrycie roślin uprawnych (Cover of cultivation) [\%] & 50 & 45 & 25 \\
\hline Pokrycie warstwy c (Cover of layer c) [\%] & 50 & 65 & 25 \\
\hline \multicolumn{4}{|l|}{ Uprawa (Cultivation): } \\
\hline Solanum tuberosum & 3 & 3 & $\mathrm{r}$ \\
\hline Vicia faba & 1 & . & . \\
\hline Brassica oleracea subsp. capitata & . & . & 2 \\
\hline Brassica oleracea var. rubra & . & . & + \\
\hline \multicolumn{4}{|c|}{ Ch. Galinsogo-Setarietum et Ch. Polygono-Chenopodion ${ }^{\star}$} \\
\hline Galinsoga ciliata & 2 & 3 & 1 \\
\hline "Lamium purpureum & + & + & . \\
\hline *Chenopodium polyspermum & $r$ & . & + \\
\hline *Sonchus oleraceus & . & . & + \\
\hline \multicolumn{4}{|c|}{ Ch. Polygono-Chenopodietalia et Ch. Stellarietea mediae* } \\
\hline Echinochloa crus-galli & 1 & 2 & + \\
\hline Chenopodium album & + & + & 2 \\
\hline "Anagalis arvensis & + & + & . \\
\hline Polygonum lapathifolium ssp. pallidum & + & . & . \\
\hline Myosotis arvensis & . & . & + \\
\hline Digitaria ischaemum & $r$ & . & . \\
\hline \multicolumn{4}{|l|}{ Inne (Others) } \\
\hline Equisetum telmateia & 2 & 1 & 1 \\
\hline Symphytum officinale & 1 & + & + \\
\hline \multicolumn{4}{|c|}{$\begin{array}{l}\text { Sporadyczne (Sporadic): Convolvulus arvensis } 1(+), 2(+), \text { Galeopsis tetrahit } 1(+), 2(r), \\
\text { Polygonum persicaria } 1(+), 2(r) \text {, Potentilla anserina } 1(+), 2(r) \text {, Ranunculus repens } 1(+), 2(r), \\
\text { Cirsium arvense } 1(r), 3(+) \text {, Betonica officinalis } 1(r) \text {, Equisetum arvense } 3(1) \text {, Capsella bursa } \\
\text { pastoris } 3(+) \text {, Plantago major } 3(+) \text {, Oxalis fontana } 3(+) \text {, Lamium maculatum } 3(r)\end{array}$} \\
\hline
\end{tabular}


Zdjęcie trzecie wykonano w Warzycach koło Jasła, na niewielkim poletku kapusty, uprawianym ręcznie, pomiędzy pasowymi uprawami Solanum tuberosum i Beta vulgaris var. crassa. Obficie występuje tam Chenopodium album, a także Galinsoga ciliata, Equisetum telmateia i E. arvense.

\section{Cirsietum rivularis}

Płaty tego zbiorowiska z wystąpieniami Equisetum telmateia znajdowano w dolinie Wierzbanówki (D u bi e l, 1984) oraz w Beskidzie Niskim (D u bi e l, S ta churska, Gawroński, 1999). Jak się wydaje jest to zbiorowisko dość częste na pogórzu, występujące na miejscach z utrzymującą się na powierzchni gruntu przez cały rok wodą. Często są to niewielkie płaty, na które negatywny wpływ mają jednostronne melioracje wodne i rozrastająca się zabudowa wiejska. Łąki te dają 1-2 pokosów, jednak wartość siana bywa ograniczana przez udział skrzypów (Equisetum telmateia, E. palustre), jaskra ostrego (Ranunculus acris), oraz mało wartościowych traw (Holcus lanatus, Anthoxanthum odoratum).

\section{Cirsietum rivularis caricetosum hartmanii}

Podzespół ten po raz pierwszy z Polski został opisany przez Dubie la $\mathrm{i}$ in. (1999) z Magurskiego Parku Narodowego. Rozwija się na wilgotnych śródleśnych polanach.

\section{Scirpetum sylvatici}

Wystąpienia Equisetum telmateia w jednym płacie tego zespołu stwierdzono w dolinie Wierzbanówki (D u b i e 1, 1984). Scirpetum sylvatici zajmował tam niewielkie, stale wilgotne powierzchnie, na glebach mineralno glejowych Podobne wystąpienia stwierdzano w Magurskim Parku Narodowym oraz na Pogórzu Wiśnickim. Ciężkowickim i Strzyżowskim. Są to zawsze bardzo małe powierzchnie, często w kompleksie z płatami łęgowymi.

\section{Zbiorowisko z Mentha longifolia}

Płaty opisywane z doliny Wierzbanówki (Dubiel, 1984) zajmowały fragmenty rowów odwadniających o mineralnym podłożu. Obserwowane przez autora tego opracowania płaty zbiorowiska z Mentha longifolia, z udziałem Equisetum telmateia należały przeważnie do Aegopodio-Menthetum longifoliae Hilbig 1972, opisywanego przez B rzeg a (1988), rzadko zaś do zbiorowisk łąkowych.

\section{Zbiorowisko z Equisetum telmateia}

Zbiorowisko to podawane jest z doliny Wierzbanówki (Dubiel, 1984). Zajmuje tam nieutrwalone zbocza o charakterze osuwiskowym, na podłożu mineralno glejowym lub brunatnym. Warunkiem występowania jest utrzymująca się w podłożu 
wilgoć. Podobne płaty autor znajdował w całym obszarze Dołów Jasielsko Sanockich oraz w Beskidzie Niskim, jednak w ich składzie florystycznym gatunki z klasy Artemisietea vulgaris przeważały nad gatunkami łąkowymi z klasy Molinio-Arrhenatheretea.

\section{Arrhenatheretum medioeuropaeum}

Wystapienie Equisetum telmateia w jednym płacie tego zbiorowiska stwierdzono w Beskidzie Niskim, na terenie Magurskiego Parku Narodowego (Dubiel, Stachurska, Gawroński, 1999). Płat ten był podsiewany mieszanką wysokoproduktywnych traw. Dominowała w nim Dactylis glomerata. Zjawisko występowania Equisetum telmateia w płatach podsiewanych łąk jest znacznie szersze, chociaż przeważnie dotyczy ląk porolnych.

\section{Arrhenatheretum medioeuropaeum brizetosum mediae}

Jest to podzespół ciepłolubny, rozwijający się w dolinie Wierzbanówki (Dubiel, 1984), na suchych siedliskach, na glebach typu pararędzin. Equisetum telmateia występuje tam tylko w jednym płacie.

\section{Zbiorowisko z Cirsium oleraceum}

Zbiorowisko to, opisywane przez Dubiela (1984) rozwija się w miejscach chłodnych, na madach, glebach brunatnych a nawet na pararędzinach. Cirsium oleraceum jest gatunkiem bardzo często występującym wespół ze skrzypem olbrzymim, zawsze tam gdzie w podłożu znajduje się wystarczająco dużo wilgoci. Częściej jednak niż w zbiorowiskach łąkowych występują razem w asocjacjach z klasy Artemisietea vulgaris.

\section{Lolio-Cynosuretum}

W literaturze jest bardzo niewiele informacji o występowaniu Equisetum telmateia na powierzchniach pastwiskowych (A da m sk a 1984). Takie wystąpienia znaleziono jednak na Pogórzu Rożnowskim (Tabela 4). We wszystkich trzech obserwowanych tam płatach dominowały gatunki z klasy Molinio-Arrhenatheretea i rzędu Arrhenatheretalia, ale tylko w pierwszym z nich gatunki związku Cynosurion przeważały nad gatunkami związku Arrhenatherion elatioris. Jednak ze względu na charakter użytkowania i fizjonomię zdecydowano o włączeniu także zdjęć pozostałych płatów do zespołu Lolio-Cynosuretum.

Zespół ten rozwinął się tam na stokach o niewielkim nachyleniu, na glebach brunatnych - kwaśnych ( $\mathrm{pH}=5,0$; mierzone kolorymetrycznie, $\mathrm{z}$ użyciem płynu Helliga). Zdjęcia ustawione są zgodnie z gradientem wilgotności. W najwilgotniejszym, trzecim zdjęciu duży udział ma Mentha longifolia. Wszystkie płaty mają fizjonomię typową dla pastwisk z pozostającymi kępami niskich niedojadów, tworzącymi się wokół, omijanych przez bydło, pędów Equisetum telmateia i bydlęcych odchodów. Wedle słów gospodarza, pędy skrzypu olbrzymiego szkodzą bydłu, dlatego nie zjada ich na świeżo, a po spożyciu ich w sianie choruje. Niedojady są wykaszane przy okazji innych prac wokół gospodarstwa. Taka forma gospodarowania utrzymywana jest na tym pastwisku od co najmniej 30 lat. 


\begin{tabular}{|c|c|c|c|}
\hline Nr zdjęcia (Successive no. of relevé) & 1 & 2 & 3 \\
\hline Data (Date) & \multicolumn{3}{|c|}{ 10.09.2000. } \\
\hline Miejsce (Locality) & Bruśnik & Bruśnik & Bruśnik \\
\hline Powierzchnia $\mathrm{m}^{2}$ (Area) $\mathrm{m}^{2}$ & 50 & 25 & 50 \\
\hline Nachylenie $^{\circ}\left(\right.$ Slope $\left.^{\circ}\right)$ & 10 & 10 & 5 \\
\hline Ekspozycja (Eksposure) & NE & NE & NE \\
\hline Pokrycie c (Cover of c layer [\%] & 100 & 95 & 100 \\
\hline \multicolumn{4}{|c|}{ Ch. All. Cynosurion ${ }^{\star}$ et Ass. Lolio-Cynosuretum } \\
\hline${ }^{\star}$ Trifolium repens & 3 & + & 1 \\
\hline Bellis perennis & r & 1 & + \\
\hline${ }^{\star}$ Cynosurus cristatus & 2 & $r$ & + \\
\hline Leontodon autumnalis & 1 & $r$ & \\
\hline \multicolumn{4}{|l|}{ D.Ass. Lolio-Cynosuretum } \\
\hline Lolium perenne & + & & \\
\hline \multicolumn{4}{|l|}{ Ch. O. Arrhenatheretalia } \\
\hline Arrhenatherum elatius & + & 3 & 3 \\
\hline Lotus corniculatus & 1 & $r$ & + \\
\hline Taraxacum officinale & + & & 1 \\
\hline Campanula patula & & $\mathrm{r}$ & + \\
\hline Daucus carota & & & 1 \\
\hline \multicolumn{4}{|l|}{ Ch. Cl. Molinio-Arrhenatheretea } \\
\hline Achillea millefolium & 1 & + & + \\
\hline Leontodon hispidus & 1 & $r$ & $r$ \\
\hline Centaurea jacea & + & + & \\
\hline Trifolium pratense & & 2 & 1 \\
\hline Lathyrus pratensis & & 1 & 1 \\
\hline Phleum pratense & & & 1 \\
\hline Plantago lanceolata & & & $r$ \\
\hline \multicolumn{4}{|l|}{ Inne (Others) } \\
\hline Equisetum telmateia & + & 2 & 2 \\
\hline Agrostis capillaris & 1 & & 1 \\
\hline Mentha Iongifolia & & + & 2 \\
\hline $\begin{array}{l}\text { Sporadyczne (Sporadic): Ranuncul } \\
\text { Festuca ovina } 1(+) \text {, Odontites serotin }\end{array}$ & $\begin{array}{l}\text { arvense } \\
3(r)\end{array}$ & (1), & \\
\hline
\end{tabular}

Valeriano-Caricetum flavae

Eutroficzne i kalcyfilne młaki niskoturzycowe są częste w całych Karpatach. Wykształcają się na stokach lekko nachylonych, w miejscach wysięków, na glebach gruntowo-glejowych. Wystapienia Equisetum telmateia w płatach tego zbiorowiska podawane są zarówno z doliny Wierzbanówki (D u bie 1, 1984) jak i z Magurskiego Parku Narodowego (Dubiel, Stachurska, Gawroński, 1999). Nie mają one dużego znaczenia dla pozyskiwania runi, jednak ich wartość środowiskowa jest ogromna ze względu na ich własności retencyjne. 


\section{Carlino-Dianthetum deltoidis}

Jest to zbiorowisko opisane po raz pierwszy z Magurskiego Parku Narodowego (Dubiel, Sta churska, Gaw rońs ki, 1999). Są to suche murawy na zboczach i lokalnych garbach. Reprezentują one stadium degradacyjne ubogiej łąki świeżej (Gladiolo-Agrostietum). W chwili obecnej zbiorowisko to nie ma znaczenia gospodarczego, jednak zdecydowano o włączeniu go do zestawienia ze względu na wykształcanie się w obszarze dawnych łemkowskich użytków rolnych.

\section{DYSKUSJA I WNIOSKI}

Equisetum telmateia, występując na tak zróżnicowanych siedliskach, wykazuje szeroką skalę ekologiczną i jednocześnie ogromne możliwości przystosowywania się do różnorodnych warunków i form użytkowania terenu. Po zajęciu nowych powierzchni z reguły trwa na nich mimo podejmowanych prób jego usunięcia, zarówno przy użyciu środków chemicznych jak i (wręcz z przeciwnym skutkiem) przy zastosowaniu głębokich zabiegów agrotechnicznych. Pozostaje na polu nawet, gdy uprawa zostanie zniszczona lub porzucona. Brak jak dotąd jakichkolwiek ocen jego wpływu na plony.

Najtrudniej wyjaśnić obecność skrzypu olbrzymiego w zbiorowiskach suchych lub przynajmniej o okresowym niedoborze wilgotności w podłożu. Bardzo prawdopodobną hipotezą jest obecność skrzypu olbrzymiego na danym terenie wcześniej, jeśli miejsce to było zajęte przez zbiorowisko innego rodzaju bardziej zasobne w wodę, może wywodzące się z kręgu zbiorowisk łęgowych, a więc naturalnych dla tego gatunku. W takim przypadku skrzyp olbrzymi musiał oprzeć się zmianom poziomu wód gruntowych, a potem przetrwać wycofywanie się gatunków, z którymi współwystępował. Jest to scenariusz opierający się wyłącznie na obserwowanej często plastyczności ekologicznej tego gatunku.

Geneza obecności skrzypu olbrzymiego w zbiorowiskach o dużej wilgotności podłoża jest zupełnie inna. Często są to asocjacje znajdujące się na początku szeregu sukcesyjnego, prowadzącego do zbiorowisk łęgowych. Mogą też być to zbiorowiska zastępcze łęgów, bardzo różnorodne, w zależności od czynnika, który przyczynił się do ich powstania, jego natężenia i czasu działania. Zawsze trwanie w czasie tych zbiorowisk będzie zależne od ingerencji człowieka, a utrzymywanie się w nich skrzypu olbrzymiego jest raczej przesądzone, tak długo, jak długo prowadzone są zabiegi agrotechniczne, a zwierciadło wód gruntowych nie opadnie zanadto.

Wszystkie zabiegi agrotechniczne mające na celu przygotowanie gleby pod uprawę, a prowadzone na tych powierzchniach, czyli orka, bronowanie, motyczenie, być może także głęboszowanie oraz zbiór ziemniaków (zarówno ręczny jak i z użyciem maszyn) działają stymulująco na rozmnażanie wegetatywne tego gatunku. Wynika to z charakterystycznej architektury jego osobników. 
Układ zawiązków pędów skrzypu olbrzymiego, zarówno płonnych jak i płodnych zostaje zdeterminowany jeszcze jesienią, gdy osobniki zaczynają ,inwestować" zgromadzone materiały zapasowe. Pędy z kłosem zarodnionośnym są przygotowane płytko pod powierzchnią gruntu, a od października można je znaleźć ponad powierzchnią gleby. Już prace dokonywane jesienią mogą więc zniszczyć rozwijające się pędy. Wiosną, kiedy następuje ich bardzo szybki wzrost ponownie dokonywana jest orka i bronowanie, co ostatecznie niszczy blisko $100 \%$ pędów płodnych. Również zawiązki pędów płonnych, znajdujące się blisko powierzchni są niszczone na tyle skutecznie, że pojawianie się na powierzchni gruntu nowych, regenerujących pędów następuje po około 4-5 tygodniach. Ta niekorzystna, na pierwszy rzut oka okoliczność powoduje intensywną fragmentację kłączy, co wzmaga rozwój i rozmnażanie wegetatywne, a zruszanie gleby stymuluje rozrost kłącza. Rozprzestrzenianie się skrzypu olbrzymiego w wyniku fragmentacji kłącza potwierdza znalezienie w Bruśniku, na polu uprawnym, po wiosennej orce 2002 roku, fragmentów kłącza z żywymi zawiązkami pędów płonnych siedem dni po ostatnich w tamtym okresie pracach polowych. Kontynuowały one wzrost do momentu pobrania ich $\mathrm{z}$ gleby. Rozprzestrzenianie się w uprawach polowych podziemnych kłączy skrzypu olbrzymiego może być bardzo szybkie. W 2001 roku, na sąsiadującym z osuwiskiem w Lisówku polu nie stwierdzono zarówno pędów płonnych jak i płodnych, podobnie wiosną 2002. Jednak w lipcu tego roku jego pędy wyrastały w rozproszeniu na powierzchni już około $100 \mathrm{~m}^{2}$.

\section{LITERATURA}

A d a m sk a M., 1982. Ekologia Equisetum telmateia Ehrh. na Pogórzu Wielickim koło PolankiHaller. Mskr. pracy magisterskiej, Zakład Ekologii Roślin Instytutu Botaniki, Uniwersytet Jagielloński, Kraków.

B rzeg A., 1988. Przegląd systematyczny zbiorowisk okrajkowych dotąd stwierdzonych i mogących występować w Polsce. Fragm. Flor. Geobot. ser. Pol. 3-4: 385-424.

Dubiel E., 1984. Dolina Wierzbanówki 10: Zbiorowiska łąkowe. Zesz. Nauk. Uniw. Jagiellońskiego, Prace Bot. 14: 51-86.

Dubiel E., Trzcińska-Tacik H., 1982. Dolina Wierzbanówki 4. Zbiorowiska roślinne pól uprawnych. Zesz. Nauk. Uniw. Jagiellońskiego, Prace Bot. 12: 51-86.

Dubiel E., Stachurska A, Gaw roński S., 1999. Nieleśne zbiorowiska roślinne Magurskiego Parku Narodowego (Beskid Niski). Zesz. Nauk. Uniw. Jagiellońskiego, Prace Bot. 33: 1-60.

Herbich J., 1982. Zróżnicowanie i antropogeniczne przemiany roślinności Wysoczyzny Staniszewskiej na Pojezierzu Kaszubskim. Monogr. Bot. 62: 1-162.

Matuszkiewicz W., 2001. Vademecum geobotanicum 3. Przewodnik do oznaczania zbiorowisk roślinnych Polski. PWN, Warszawa, ss. 1-537.

Wróbel D., 2003. Występowanie Equisetum telmateia Ehrh. w antropogenicznych zbiorowiskach roślinnych na terenie Karpat i Dolnego Śląska. Fragm. Flor. Geobot. Pololonica 10: $27-55$. 


\section{Streszczenie}

Skrzyp olbrzymi Equisetum telmateia Ehrh. pojawia się dość często w zbiorowiskach użytków rolnych. W oparciu o literaturę i oryginalne prace badawcze wykonano ich listę, zawierającą 16 zbiorowisk, zespołów i podzespołów (Vicietum tetraspermae, Aphano-Matricarietum, Lathyro-Melandrietum noctiflori, Echinochloo-Setarietum, Galinsogo-Setarietum, Cirsietum rivularis, Cirsietum rivularis caricetosum hartmanii, Scirpetum sylvatici, zbiorowisko z Mentha longifolia, zbiorowisko z Equisetum telmateia, Arrhenatheretum medioeuropaeum, Arrhenatheretum medioeuropaeum brizetosum mediae, zbiorowisko z Cirsium oleraceum, Lolio-Cynosuretum, Valeriano-Caricetum flavae, Carlino-Dianthetum deltoidis). Występowanie skrzypu olbrzymiego w tak różnorodnych zbiorowiskach wskazuje na jego szeroką skalę ekologiczną i zdolność znoszenia różnych form presji antropogenicznej. Pojawianie się tego gatunku w uprawach rolnych może wynikać z wcześniejszej obecności na terenie wziętym pod uprawę lub też z rozprzestrzenienia się wegetatywnego jego kłączy. 